\title{
Pengaruh Penerapan Metode Akuntansi Keuangan Daerah, Transparansi Publik dan Kegiatan Pengendalian terhadap Akuntabalitas Keuangan di Kantor kecamatan Kota Medan
}

\author{
Nur Dwi Wulandari \\ Universitas Sumatera Utara \\ Dirgafakhri86@gmail.com
}

\begin{abstract}
ABSTRAK
Perkembangan akuntansi sektor publik di Indonesia semakin pesat seiring dengan adanya era baru dalam pelaksanaan otonomi daerah, warga negara yang semakin kritis dan cerdas menginginkan terciptanya suatu pemerintahan yang transparansi serta pengawasan internalnya yang bisa dipertanggungjawabkan. Penelitian ini bertujuan untuk mencari pengaruh penerapan metode akuntansi keuangan daerah, transparansi publik dan kegiatan pengendalian terhadap akuntabilitas keuangan. Jenis penelitian kualitatif yaitu metode penelitian yang memfokuskan pada aspek suatu pemahaman secara mendalam terhadap suatu masalah daripada melihat permasalahan untuk penelitian generalisasi. Sampel dalam penelitian ini adalah 30 responden. Metode analisis data yang digunakan adalah model regresi linier berganda, pandangan klasik, uji F dan uji t dengan menggunakan software SPSS. Dari data hasil penelitian penerapan metode akuntansi keuangan daerah, transparansi publik dan kegiatan pengendalian secara parsial berpengaruh signifikan terhadap akuntabilitas keuangan pada seluruh Kantor Kecamatan di Kota Medan karena hasil signifikan t $<0,05$. Penerapan metode akuntansi keuangan daerah, transparansi publik dan kegiatan pengendalian secara simultan berpengaruh signifikan terhadap akuntabilitas keuangan pada seluruh Kantor Kecamatan di Kota Medan karena hasil signifikan $\mathrm{F}<0,05$. Koefisien determinasi dalam hal ini berarti 89,4\% akuntabilitas keuangan dapat diperoleh dan dijelaskan oleh penerapan metode akuntansi keuangan daerah, transparansi publik dan kegiatan pengendalian. Sedangkan sisanya 10,6\% dijelaskan oleh faktor lain atau variable diluar model. Penerapan sistem akuntansi keuangan daerah, transparansi publik dan aktivitas pengendalian berpengaruh secara parsial berpengaruh positif dan signifikan terhadap akuntabilitas keuangan di Kantor Kecamatan Kota Medan. Penerapan sistem akuntansi keuangan daerah, transparansi publik dan aktivitas pengendalian berpengaruh secara simultan berpengaruh positif dan
\end{abstract}


signifikan terhadap akuntabilitas keuangan di Kantor Kecamatan Kota Medan.

Kata kunci : penerapan metode akuntansi keuangan daerah, transparansi publik dan kegiatan pengendalian, akuntabilitas keuangan

\section{PENDAHULUAN}

Perkembangan akuntansi publik di Indonesia semakin berkembang berbarengan dengan adanya era baru dalam pelaksanaan otonomi daerah, warga negara yang semakin cerdas mengharapkan terciptanya suatu pemerintahan yang terbuka serta pengawasan internalnya yang bisa dipertanggungjawabkan. Akuntabilitas merupakan pertanggungjawaban mengenai integritas keuangan, pengungkapan, dan ketaatan terhadap peraturan perundang-undangan. Sasaran pertanggungjawaban ini adalah laporan keuangan yang dituangkan dan peraturan perundangundangan yang berlaku yang mencakup penerimaan, penyimpanan, dan pengeluaran uang oleh instansi pemerintah. Di dalam pengelolaan keuangan negara membutuhkan pemerintahan yang transparan dan akuntabel. Transparansi disebut juga memberikan informasi keuangan yang terbuka kepada setiap orang bahwa setiap orang memiliki hak untuk melihat transparansi dan menyeluruh atas pertanggungjawaban pemerintah dalam pengelolaan sumber daya yang dipercayakan kepadanya dan ketaatannya pada peraturan perundang-undangan. Akuntabilitas adalah mempertanggungjawabkan pengelolaan sumber daya serta pelaksanaan kebijakan yang dipercayakan kepada materi pelaporan dalam mencapai tujuan yang telah ditetapkan secara periodik.

Adapun penelitian terdahulu terhadap penelitian ini adalah Soleha (2014), Pengaruh Penerapan Sistem Akuntansi Keuangan Daerah Dan Aktivitas Pengendalian Terhadap Akuntabilitas Keuangan: Studi Pada SKPD Kabupaten/Kota Propinsi Banten.

Hasil yang ada menunjukkan bahwa implementasi sistem keuangan daerah dan aktivitas pengendalian memberikan pengaruh simultan yang positif dan signifikan yaitu mencapai 55,20\% terhadap akuntabilitas keuangan. Hasil kedua menunjukkan bahwa implementasi sistem keuangan daerah memberikan pengaruh yang positif dan signifikan mencapai 20,05\% atas akuntabilitas keuangan. Hasil yang ketiga menunjukkan implementasi aktivitas pengendalian memberikan pengaruh yang positif dan signifikan mencapai $35,15 \%$ atas akuntabilitas keuangan.

Fathia (2017), Pengaruh Penerapan Sistem Akuntansi Pemerintah Daerah, Penerapan Anggaran Berbasis Kinerja, Kejelasan Sasaran Anggaran, Sistem Pelaporan Kinerja Dan Pengendalian Akuntansi Terhadap Akuntabilitas Kinerja Instansi Pemerintah (AKIP) (Study Kasus SKPD di Provinsi Riau), Hasil penelitian menunjukkan bahwa Penerapan Sistem Akuntansi Pemerintah Daerah, Penerapan Anggaran Berbasis Kinerja, Kejelasan Sasaran Anggaran, Sistem Pelaporan Kinerja Dan Pengendalian Akuntansi berpengaruh positif dan signifikan Terhadap Akuntabilitas Kinerja Instansi Pemerintah. Setiyawan

Setiyawan(2016), Analisis Pengaruh Akuntabilitas Publik, Transparansi Publik Dan Pengawasan Terhadap Kinerja Satuan Kerja Perangkat Daerah Di Kabupaten Bungo, Hasil penelitian menunjukkan bahwa Hasil penelitian menunjukan bahwa secara simultan akuntabilitas publik, transparansi publik, pengawasan, dan pengelolaan keuangan daerah, berpengaruh terhadap kinerja SKPD pada Pemerintah Kabupaten Bungo. Secara parsial akuntabilitas publik, transparansi publik, pengawasan, dan pengelolaan keuangan daerah berpengaruh terhadap kinerja 
SKPD pada Pemerintah Kabupaten Bungo.

Metode akuntansi keuangan daerah merupakan bagian dari metode pengendalian di dalam pemerintahan dimana sebagai proses yang integral pada tindakan dan kegiatan yang dilakukan secara terus menerus oleh pimpinan dan seluruh pegawai untuk memberikan keyakinan memadai atas tercapainya tujuan organisasi yang nantinya akan mengahsilkan kegiatan yang efektif dan efisien, keandalan pelaporan keuangan, pengamanan aset negara, dan ketaatan terhadap peraturan perundang-undangan.

1. Masalah yang menyangkut penerapan metode akuntansi keuangan daerah yaitu masih terdapat pemahaman implementasi metode akuntansi keuangan daerah belum terlaksana dengan baik.

2. Masalah yang menyangkut mengenai transparansi publik yaitu yaitu masih terdapat kecamatan Kota Medan yang belum mengimplementasikan transparansi tersebut seperti dalam hasil laporan, sehingga sampai saat ini masyarakat masih merasakan belum optimalnya kinerja Kecamatan Kota Medan dalam memberikan pelayanan publik.

3. Kegiatan pengendalian yaitu kenyataannya selama ini kinerja anggaran dalam proses penyusunan, pembahasan sampai pada penetapan APBD serta Laporan Keterangan Pertanggung Jawaban (LKPJ), masih belum terealisasi sehingga perhatian lebih berfokus pada besarnya anggaran. Kinerja anggaran lebih mengutamakan penyerapan anggaran sehingga banyak anggaran digunakan untuk hal-hal yang tidak perlu, terjadi ketidakefisiensi anggaran, dan banyak penggunaan anggaran yang menyimpang dengan tujuan atau target kebijakan pemerintah.

\section{Metode Akuntansi Keuangan Daerah}

\section{LANDASAN TEORI}

Metode akuntansi yang meliputi proses pencatatan, penggolongan, penafsiran, peringkasan transaksi atau kejadian keuangan serta pelaporan keuangan dalam rangka pelaksanaan APBD (Erlina, 2013:6). Indikator metode akuntansi keuangan daerah yaitu:

1. Basis akuntansi

2. Unsur-unsur laporan realisasi anggaran

3. Penyusunan APBD sesuai dengan Permendagri Nomor 13 Tahun 2006

4. Penyusunan laporan keuangan dari data PP 71 Tahun 2004

\section{Transparansi Publik}

Memberikan informasi keuangan yang terbuka dan jujur kepada masyarakat dari data pertimbangan bahwa masyarakat memiliki hak untuk mengetahui secara terbuka dan menyeluruh atas pertanggungjawaban pemerintah dalam pengelolaan sumber daya yang dipercayakan kepadanya dan ketaatannya pada peraturan perundang-undangan. (Erlina, 2013:66). Indikator transparansi publik yaitu:

1. Transparansi dalam pengelolahan APBD

2. Keterbukaan alam penerimaan dan penggunaan dana di tiap-tiap SKPD

3. Kemudahan mengakses data

4. Metode komunikasi organisasi

\section{Kegiatan Pengendalian}

Memastikan bahwa kegiatan dapat berjalan sesuai dengan apa yang seharusnya atau seperti apa yang telah direncanakan (Aren, 2010:76). Indikator kegiatan pengendalian yaitu: 
1. Harus sesuai prinsip akuntansi

2. Perekrutan dan pengembangan SDM

3. Tugas prosedur dalam pekerjaan

4. Kesesuaian

5. Pemisahan tugas

6. Independen

\section{Akuntabilitas Keuangan}

Pertanggungjawaban pengelolaan sumber daya serta pelaksanaan kebijakan yang dipercayakan kepada unit organisasi pemerintah dalam rangka pencapaian tujuan yang telah ditetapkan mekemudiani laporan keuangan pemerintah secara priodik. Indikator akuntabilitas keuangan yaitu:

1. Pengelolaan APBD disajikan terbuka,cepat dan tepat kepada masyarakat

2. Indikator hasil kinerja yang akan dicapai ditetapkan dan telah digunakan untuk mengevaluasi pengelolaan APBD

3. Proses dan pertanggungjawaban APBD diawasi secara terus menerus

4. Penyajikan APBD telah menyertakan informasi masa kemudian.

5. Dalam mengevaluasi APBD hanya memperbandingkan dengan realisasi /sesungguhnya

6.

\section{METODE PENELITIAN}

Jenis penelitian ini dapat dinyatakan sebagai penelitian kualitatif yaitu metode penelitian yang menekankan pada aspek suatu pemahaman secara mendalam terhadap suatu masalah daripada melihat permasalahan untuk penelitian generalisasi (Sugiyono, 2010).

\section{Populasi}

Menurut Erlina (2011:78) "Populasi adalah sekelompok entitas yang lengkap yang dapat berupa orang, kejadian, atau benda yang mempunyai karakteristik tertentu, yang berada dalam suatu wilayah dan memenuhi syarat-syarat tertentu yang berkaitan dengan masalah penelitian". Populasi dalam penelitian ini adalah seluruh pegawai di Kantor Kecamatan Kota Medan, sehingga total populasi yang menjadi sampel adalah sebanyak 21 Kecamatan.

\section{Sampel}

Menurut Erlina (2011:79), sampel adalah bagian dari jumlah dan karakteristik yang dimiliki oleh populasi. Pengambilan sampel dalam penelitian ini menggunakan metode accidental sampling yaitu non-probabilitas sampling teknik dimana subyek dipilih karena aksesibilitas nyaman, kedekatan mereka kepada peneliti dan secara kebetulan. Subyek dipilih hanya karena mereka paling mudah untuk merekrut studi dan peneliti tidak mempertimbangkan memilih responden yang mewakili seluruh populasi. Kriteria penelitian yang dilakkan di 10 Kantor Kecamatan di Kota Medan yaitu Bagian Keuangan, Bendahara dan Camat.

\section{Jenis dan Sumber Data}

Penelitian ini menggunakan data kualitatif dan data primer diperoleh dengan menggunakan metode survei yaitu mekemudiani kuesioner. Dengan mendatangi sumber data yaitu satu per satu calon responden, menanyakan apakah calon memenuhi persyaratan sebagai calon responden untuk mengisi kuesioner. 


\section{Teknik Pengumpulan Data}

Teknik pengumpulan pengumpulan data merupakan suatu cara yang metodeatis dan objektif untuk memperoleh atau mengumpulkan keterangan-keterangan yang bersifat lisan maupun tulisan. Adapun teknik pengumpulan data yang digunakan dalam penelitian ini adalah dengan kuisioner/angket yaitu kuisioner langsung, yaitu daftar pertanyaan dikirim atau diserahkan langsung kepada orang yang di mintai pendapat, keyakinan atau diminta menceritakan tentang dirinya sendiri.

\section{HASIL DAN PEMBAHASAN}

Pengaruh penerapan sistem akuntansi keuangan daerah terhadap akuntabilitas keuangan. Pengujian signifikan dengan kriteria pengambilan keputusan: Ha diterima dan $\mathrm{H} 0$ ditolak, apabila thitung $>\mathrm{t}_{\text {tabel }}$ atau Sig. $\mathrm{t}<\alpha$ Ha ditolak dan $\mathrm{HO}$ diterima, apabila $\mathrm{t}_{\text {hitung }}<\mathrm{t}_{\text {tabel }}$ atau Sig. $\mathrm{t}>\alpha$ thitung sebesar 2,109 sedangkan tabel sebesar 1,705 dan signifikan sebesar 0,045, sehingga thitung 2,109 $>\mathrm{t}_{\text {tabel }} 1,705$ dan signifikan $0,045<0,05$, maka Ha diterima dan $\mathrm{H} 0$ ditolak, yang menyatakan penerapan sistem akuntansi keuangan daerah berpengaruh signifikan secara parsial terhadap akuntabilitas keuangan.

\section{Pengaruh transparansi publik terhadap akuntabilitas keuangan.}

Pengujian signifikan dengan kriteria pengambilan keputusan:

Ha diterima dan $\mathrm{H} 0$ ditolak, apabila thitung $>\mathrm{t}_{\text {tabel }}$ atau Sig. $\mathrm{t}<\alpha$

Ha ditolak dan $\mathrm{H} 0$ diterima, apabila thitung $<t_{\text {tabel }}$ atau Sig. $\mathrm{t}>\alpha$

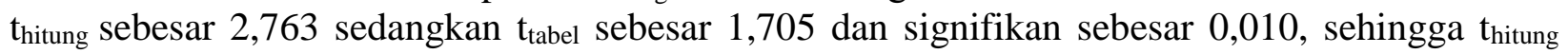
$2,763>t_{\text {tabel }} 1,705$ dan signifikan $0,010<0,05$, maka Ha diterima dan H0 ditolak, yang menyatakan transparansi publik berpengaruh signifikan secara parsial terhadap akuntabilitas keuangan.

\section{Pengaruh aktivitas pengendalian terhadap akuntabilitas keuangan.}

Pengujian signifikan dengan kriteria pengambilan keputusan:

Ha diterima dan $\mathrm{H} 0$ ditolak, apabila $\mathrm{t}_{\text {hitung }}>\mathrm{t}_{\text {tabel }}$ atau Sig. $\mathrm{t}<\alpha$

Ha ditolak dan $\mathrm{H} 0$ diterima, apabila thitung $<\mathrm{t}_{\text {tabel }}$ atau Sig. $\mathrm{t}>\alpha$

thitung sebesar 6,814 sedangkan tabel sebesar 1,705 dan signifikan sebesar 0,000, sehingga thitung $6,814>t_{\text {tabel }} 1,705$ dan signifikan $0,000<0,05$, maka Ha diterima dan $\mathrm{H} 0$ ditolak, yang menyatakan aktivitas pengendalian berpengaruh signifikan secara parsial terhadap akuntabilitas keuangan.

\section{Pengaruh Penerapan Metode Akuntansi Keuangan Daerah Terhadap Akuntabilitas Keuangan}

Hasil menunjukkan bahwa penerapan metode akuntansi keuangan daerah berpengaruh positif dan signifikan terhadap akuntabilitas keuangan, dimana thitung $2,109>t_{\text {tabel }} 1,705$ dan signifikan $0,045<0,05$. Hal penelitian ini sesuai dengan penelitian Soleha (2014) dan Fathia (2017), yang menunjukkan bahwa penerapan metode akuntansi keuangan daerah berpengaruh positif dan signifikan terhadap akuntabilitas keuangan. Penelitian ini menerangkan bahwa laporan keuangan pemerintah daerah yang dihasilkan mekemudiani proses akuntansi merupakan bentuk transparansi dan akuntabilitas pengelolaan keuangan publik. Guna dapat menghasilkan laporan keuangan yang semakin baik (tantangan) dibutuhkan tenaga-tenaga akuntansi terampil pada 
pemerintah daerah, hal ini dapat dilakukan melaui kegiatan bimbingan teknis akuntansi bagi pegawai pemerintah daerah yang ditugaskan sebagai pengelola keuangan atau mekemudiani rekrutmen pegawai baru yang memiliki kemampuan akuntansi keuangan daerah. Tidak hanya tenaga-tenaga akuntansi terampil tersebut, juga dibutuhkan adanya metode dan prosedur pembukuan yang memadai dan kebijakan akuntansi sebagai pedoman pegawai dalam mengelola keuangan daerah (Barton, 2007:50).

\section{Pengaruh Transparansi Publik Terhadap Akuntabilitas Keuangan}

Hasil menunjukkan bahwa transparansi publik berpengaruh positif dan signifikan terhadap akuntabilitas keuangan, dimana thitung 2,763 $>t_{t a b e l} 1,705$ dan signifikan $0,010<0,05$. Hal penelitian ini sesuai dengan penelitian Setiawan (2016), yang menunjukkan bahwa transparansi publik berpengaruh positif dan signifikan terhadap akuntabilitas keuangan. Penelitian ini menerangkan bahwa dalam mengelola keuangan negara, dibutuhkan pemerintahan yang bersih, transparan dan akuntabel. Transparansi adalah memberikan informasi keuangan yang terbuka dan jujur kepada masyarakat dari data pertimbangan bahwa masyarakat memiliki hak untuk mengetahui secara terbuka dan menyeluruh atas pertanggungjawaban pemerintah dalam pengelolaan sumber daya yang dipercayakan kepadanya dan ketaatannya pada peraturan perundangundangan. Menurut Muda (2014), akuntabilitas adalah mempertanggungjawabkan pengelolaan sumber daya serta pelaksanaan kebijakan yang dipercayakan kepada entitas pelaporan dalam mencapai tujuan yang telah ditetapkan secara periodik.

\section{Pengaruh Kegiatan Pengendalian Terhadap Akuntabilitas Keuangan}

Hasil menunjukkan bahwa kegiatan pengendalian berpengaruh positif dan signifikan terhadap akuntabilitas keuangan, dimana $t_{\text {hitung }} 6,814>t_{\text {tabel }} 1,705$ dan signifikan $0,000<0,05$. Hal penelitian ini sesuai dengan penelitian Setiawan (2016), yang menunjukkan bahwa kegiatan pengendalian berpengaruh positif dan signifikan terhadap akuntabilitas keuangan. Penelitian ini menerangkan bahwa peraturan Pemerintah Nomor 60 Tahun 2008 mendefinisikan metode pengendalian intern sebagai proses yang integral pada tindakan dan kegiatan yang dilakukan secara terus menerus oleh pimpinan dan seluruh pegawai untuk memberikan keyakinan memadai atas tercapainya tujuan organisasi mekemudiani kegiatan yang efektif dan efisien, keandalan pelaporan keuangan, pengamanan aset negara, dan ketaatan terhadap peraturan perundangundangan.

\section{Pengaruh Penerapan Metode Akuntansi Keuangan Daerah, Transparansi Publik dan Kegiatan Pengendalian Terhadap Akuntabilitas Keuangan}

Hasil menunjukkan bahwa secara simultan penerapan metode akuntansi keuangan daerah, transparansi publik dan kegiatan pengendalian berpengaruh positif dan signifikan terhadap akuntabilitas keuangan, dimana $F_{\text {hitung }} 82,482>F_{\text {tabel }} 2,98$ dan signifikan 0,000 $<0,05$. Hal penelitian ini sesuai dengan penelitian Soleha (2014), Fathia (2017) dan Setiawan (2016), yang menunjukkan bahwa penerapan metode akuntansi keuangan daerah dan transparansi publik berpengaruh positif dan signifikan terhadap akuntabilitas keuangan. Penelitian ini menerangkan bahwa dengan meningkatnya penerapan metode akuntansi keuangan daerah dan transparansi publik, maka akuntabilitas keuangan akan meningkat. 


\section{KESIMPULAN}

Dari penelitian dan pembahasan pada bab sebelumnya, maka dapat diambil kesimpulan sebagai berikut: Penerapan metode akuntansi keuangan daerah, transparansi publik dan kegiatan pengendalian berpengaruh secara parsial berpengaruh positif dan signifikan terhadap akuntabilitas keuangan di Kantor Kecamatan Kota Medan. Penerapan metode akuntansi keuangan daerah, transparansi publik dan kegiatan pengendalian berpengaruh secara simultan berpengaruh positif dan signifikan terhadap akuntabilitas keuangan di Kantor Kecamatan Kota Medan.

\section{DAFTAR PUSTAKA}

Arens, A.A. et. al. 2010. Auditing and Assurance Services - An Integrated Approach. New York: Pearson Education.

Barton, Allan. 2008. Accrual Accounting and Budgeting System Issues In Australian Goverments. Australian.

Chabib, Soleh dan Rochmansjah, Heru. 2010. Pengelolaan Keuangan dan Aset Daerah. Bandung: Fokus media.

Dhaka, 2014. Ensuring Transparancy and Accountability in Financial Sector. The Financial Express.

Erlina dan Rasdiato, 2013. Akuntansi Keuangan Daerah Berbasis Akrual. Brama Ardian. Medan.

Erlina, 2011. Metodologi Penelitian, USU Press, Medan.

Farzad, Kamran and Mostafa, 2012. "Public Accountability and Government Financial Reporting”, African Journal of Bussiness Management Vol 6 (29), pp.8475-8482.

Fathia, Nurul. 2017. Pengaruh Penerapan Metode Akuntansi Pemerintah Daerah, Penerapan Anggaran Berbasis Kinerja, Kejelasan Sasaran Anggaran, Metode Pelaporan Kinerja Dan Pengendalian Akuntansi Terhadap Akuntabilitas Kinerja Instansi Pemerintah (AKIP) (Study Kasus SKPD di Provinsi Riau). Universitas Pekanbaru. JOM Fekon Vol. 4 No. 1 (Februari) 2017.

Ghozali. 2011. Aplikasi Analisis Multivariate dengan Program IBM SPSS19, Semarang: Penerbit Universitas Diponegoro. Semarang.

Halim, Abdul. 2015. Akuntansi Keuangan Daerah, Salemba Empat:Jakarta.

Keputusan Menteri Keuangan No.355 / KMK07 Tahun 2001, Tentang Pajak Penjualan Atas Barang Mewah.

Laura \& Manuel, 2015. "Determining Factors Of Transparency And Accountability in Local Governments: A Meta-Analytic Study”. Journal Of Local Self-Government: Lex Localis.

Jurnal Insitusi Politeknik Ganesha Medan

Juripol, Volume 4 Nomor 1 Maret 2021 
Mamesah, D,J. 2015. Metode Administrasi Keuangan Daerah. Jakarta:Pustaka Utama.

Muda, I., \& Rasdianto, M. S. L. (2014). Implementation of the Cash Revenue System: A Case Studyinthe Local Government Task Forces' Units of North Sumatera Province, Indonesia. Information Management \& Business Review, 6(2).

Peraturan Pemerintah Nomor 71 Tahun 2004, tentang Standar Akuntansi Pemerintahan.

Peraturan Pemerintah Republik Indonesia Nomor 71 Tahun 2010 tentang Standar Akuntansi Pemerintahan.

Peraturan Pemerintah Republik Indonesia Nomor 24 Tahun 2005 tentang Standar Akuntansi Pemerintahan.

Peraturan Pemerintah Nomor 105 Tahun 2000, tentang Pengelolaan Dan Pertanggungjawaban Keuangan Daerah-Direktorat Jenderal Perimbangan Keuangan.

Peraturan Pemerintah Nomor 108 Tahun 2000 Pasal 2, tentang instrumen pelaksanaan pemberhentian kepala daerah.

Peraturan Dalan Negeri Nomor 13 Tahun 2006, tentang Pedoman Pengelolaan Keuangan Daerah.

Peraturan Surat Menteri Dalam Negeri dan Otonomi Daerah Nomor 903 / 2735/ SJ tanggal 17 November 2000 tentang Pedoman Umum Penyusunan dan Pelaksanaan APBD tahun anggaran 2001.

Peraturan Pemerintah Nomor 60 Tahun 2008, tentang Metode Pengendalian Intern Pemerintah.

Priyatno, Duwi, 2009. SPSS untuk Analisis Korelasi, Regresi, dan Multivariate. Gava Media, Yogyakarta.

Rasdianto, N.,\& Muda, I. (2014). Analysis on the Timeliness of the Accountability Reportby theTreasurerSpending in Task Force Units in Indonesia.International Journal of AcademicResearch inAccounting,Finance and Management Sciences, 4(4), 176-190.

Setiyawan, Hari Eka. (2016). Analisis Pengaruh Akuntabilitas Publik, Transparansi Publik Dan Pengawasan Terhadap Kinerja Satuan Kerja Perangkat Daerah Di Kabupaten Bungo. Universitas Jambi. Jurnal Perspektif Pembiayaan dan Pembangunan Daerah Vol. 4 No. 1, JuliSeptember 2016 ISSN: 2338-4603 (print); 2355-8520 (online).

Soleha, Nurhayati. (2014). Pengaruh Penerapan Metode Akuntansi Keuangan Daerah Dan Kegiatan Pengendalian Terhadap Akuntabilitas Keuangan: Studi Pada SKPD Kabupaten/Kota Propinsi Banten. Universitas Sultan Ageng Tirtayasa. Jurnal Etikonomi Vol. 13 No. 1 April 2014.

Jurnal Insitusi Politeknik Ganesha Medan

Juripol, Volume 4 Nomor 1 Maret 2021 
Sugiyono, 2010. Metode Penelitian Kuantitatif Kualitatif dan R\&D; Penerbit : CV Alfabeta, Bandung.

Surat Menteri Dalam Negeri dan Otonomi Daerah Nomor 903 / 2735 / SJ tanggal 17 November 2000 tentang Pedoman Umum Penyusunan dan Pelaksanaan APBD tahun anggaran 2001

Torres, Lourdes. 2014. Accounting and Accountability: Recent Developments In Government Financial Information Systems, University of Zaragoza, Spain.

Undang-Undang Republik Indonesia Nomor 6 Tahun 1975, Tentang Cara Penyusunan Anggaran Pendapatan Dan Belanja Daerah, Pelaksanaan Tata Usaha Keuangan Daerah, Dan Penyusunan Perhitungan Anggaran Pendapatan Dan Belanja Daerah-Daerah.

Undang-Undang Republik Indonsia Nomor 5 Tahun 1975, tentang Perubahan Undang-Undang Republik Indonesia Nomor 16 Tahun 1969 Tentang Susunan Dan Kedudukan Majelis Permusyawaratan Rakyat, Dewan Perwakilan Rakyat Dan Dewan Perwakilan Rakyat Daerah.

Undang-Undang Republik Indonesia Nomor 22 Tahun 1999, tentang Pemerintahan Daerah.

Undang-Undang Republik Indonesia Nomor 25 Tahun 1999, tentang Perimbangan Keuangan Pusat dan Daerah-Direktorat Jenderal Perimbangan Keuangan.

Undang-Undang Republik Indonesia Nomor 17 Tahun 2003 tentang Keuangan Negara

Undang-Undang Republik Indonesia Nomor 01 Tahun 2004 tentang Perbendaharaan Negara.

Undang-Undang Republik Indonesia Nomor 15 tahun 2004 tentang Pemeriksaan Pengelolaan dan Tanggung Jawab Keuangan Negara.

Undang-Undang Republik Indonesia Nomor 01 Tahun 2004, tentang Laporan Keuangan Pemerintah Daerah.

http://www.rmolsumut.com/read/2017/04/10/46544/Pemko-Medan-Gagal-Penuhi-Target-PAD2016-. (Diakses hari Jumat, tanggal 10 November 2017, Pukul:14.00 Wib).

Jurnal Insitusi Politeknik Ganesha Medan

Juripol, Volume 4 Nomor 1 Maret 2021 